Lavin et al. 1

LAVIN ET AL.: NEW COMBINATIONS IN COURSETIA

\title{
DNA Sequence Variation among Conspecific Accessions of the Legume Coursetia caribaea Reveal Geographically Localized Clades Here Ranked as Species
}

\section{Matt Lavin, ${ }^{1,10}$ R. Toby Pennington, ${ }^{2}$ Colin E. Hughes, ${ }^{3}$ Gwilym P. Lewis, ${ }^{4}$ Alfonso Delgado-Salinas, ${ }^{5}$ Rodrigo Duno de Stefano, ${ }^{6}$ Luciano P. de Queiroz, ${ }^{7}$ Domingos Cardoso, ${ }^{8}$ and Martin F. Wojciechowski9}

${ }^{1}$ Plant Sciences and Plant Pathology, Montana State University, Bozeman, Montana 59717, USA.

${ }^{2}$ Royal Botanic Garden Edinburgh, 20A Inverleith Row, Edinburgh, Scotland, EH3 5LR, UK.

${ }^{3}$ University of Zurich, Department of Systematic and Evolutionary Botany, Zollikerstrasse 107, 8008 Zurich, Switzerland.

${ }^{4}$ Comparative Plant and Fungal Biology Department, Royal Botanic Gardens, Kew, Richmond, Surrey TW9 3AB, UK.

${ }^{5}$ Universidad Nacional Autónoma de México, Instituto de Biología, Departamento de Botánica, Apartado Postal 70233, 04510 Ciudad de México, México.

${ }^{6}$ Herbarium, Centro de Investigación Científica de Yucatán, A. C., Calle 43. No. 130, Col. Chuburná de Hidalgo, 97200 Mérida, Yucatán, México.

${ }^{7}$ Programa de Pós-Graduação em Botânica, Universidade Estadual de Feira de Santana, Av. Transnordestina, s/n, Novo Horizonte, 44036-900, Feira de Santana, Bahia, Brazil.

${ }^{8}$ National Institute of Science and Technology in Interdisciplinary and Transdisciplinary Studies in Ecology and Evolution (INCT IN-TREE), Instituto de Biologia, Universidade Federal da Bahia, Rua Barão de Jeremoabo, Ondina, 40170-115, Salvador, Bahia, Brazil.

${ }^{9}$ School of Life Sciences, Arizona State University, Tempe, Arizona 85287-4501, USA.

${ }^{10}$ Author for correspondence (mlavin@montana.edu) 
Abstract-Coursetia caribaea is geographically and morphologically the most variable species in the genus Coursetia and in the tribe Robinieae (Leguminosae, Papilionoideae). Because of potentially undetected species, we assessed the phylogenetic relationships among the eight taxonomic varieties of C. caribaea. Sampling included nuclear ribosomal internal transcribed spacer sequences from 489 Robinieae accessions representing all varieties of $C$. caribaea and 38 of the 40 species of Coursetia, in addition to chloroplast trnD-trnT sequences from 186 accessions. Separate and combined phylogenetic analyses resolved a clade of conspecific accessions of the Bolivian C. caribaea var. astragalina as sister to the central Andean Coursetia grandiflora clade. Also distantly related to Coursetia caribaea var. caribaea accessions were those of the coastal Oaxacan C. caribaea var. pacifica, which formed the sister clade to accessions of the central Andean C. caribaea var. ochroleuca. The estimated mean ages of the stem clades for these three lineages, 11, 7.7, and 7.7 Ma, respectively, contrasted to the estimated mean ages of the corresponding crown clades of 0,0 , and $1.5 \mathrm{Ma}$. The contrasting stem and crown ages suggest that these taxa, appropriately ranked as species, Coursetia astragalina, Coursetia diversifolia, and Coursetia ochroleuca, each have persisted over evolutionary time frames as distinct geographically localized populations in seasonally dry tropical forests and woodlands.

Keywords—Neotropics, Papilionoideae, phylogenetics, seasonally dry forests, taxonomy. 
The papilionoid legume tribe Robinieae (Leguminosae) comprises 11 genera and 77 mostly woody species that generally inhabit seasonally dry topical forests and woodlands (SDTFs) and secondarily pine-oak woodlands (Lavin and Sousa 1995; Lavin et al. 2003). Molecular phylogenetic analyses of Robinieae generally have revealed a pattern of coalescence of geographically confined conspecific samples (Duno-de-Stefano et al. 2010; Queiroz and Lavin 2011; Pennington et al. 2011; Pennington and Lavin 2016). Estimated mean ages of the stem clades of such species geographically confined to the Yucatán region, local inter-Andean valleys, or parts of the Brazilian caatinga have averaged over several million years (e.g., Duno-deStefano et al. 2010; Särkinen et al. 2012; Queiroz and Lavin 2011). This pattern is thought to be more representative of woody plant species inhabiting highly seasonally tropical environments (e.g., Cyathostegia; Pennington et al. 2010; Särkinen et al. 2012) than for woody plant species inhabiting adjacent tropical savannas and wet forests (e.g., species of the genus Inga; Lavin 2006; Pennington et al. 2009; Pennington and Lavin 2016; Dexter et al. 2017).

Generally inhabiting SDTFs and adjacent pine-oak woodlands, Coursetia caribaea (Jacq.) Lavin ranges from southeastern Arizona, USA, to Mexico and Central America, the Caribbean Basin, northern South America, and along the Andes from Venezuela to northern Bolivia. Lavin (1988) recognized eight taxonomic varieties within C. caribaea, the most morphologically variable and geographically widespread species in the genus and in the tribe Robinieae. These included five varieties from Mexico and adjacent Arizona, USA. Listed from north to south, these are Coursetia caribaea vars. sericea (A. Gray) Lavin, tomentosa Lavin, trifoliolata (Rydberg) Lavin, pacifica, (M. Sousa \& Lavin) Lavin, and chiapensis (Rydberg) Lavin (Lavin 1988; Supplemental Map). Two additional South American varieties, Coursetia caribaea vars. astragalina (Kunth) Lavin and ochroleuca (Jacq.) Lavin come from southern Colombia, 
Ecuador, Peru, and west central Bolivia. The most morphologically variable and geographically widespread of the eight, Coursetia caribaea var. caribaea, nearly encompasses the geographical distribution of the other seven varieties (Lavin 1988; Supplemental Map). Sympatry is not common among these varieties.

We focus on this geographically widespread and morphologically variable species because ongoing phylogenetic analyses of nuclear ribosomal DNA 5.8S and flanking internal transcribed spacers (the nrDNA ITS region) and chloroplast sequences revealed overlooked species (e.g., Duno-de-Stefano et al. 2010) and an underlying evolutionary process involving evolutionary persistence of localized populations, which is likely common to SDTFs (Pennington and Lavin 2016). In our other studies of overlooked species variation in Coursetia and related genera (e.g., Queiroz and Lavin 2011; Pennington et al. 2011; Pennington and Lavin 2016), we argued that certain of these lineages were worthy of distinction at the species level using a unified species concept (de Queiroz 2007). This and our other studies speak to a general evolutionary finding that woody species inhabiting highly seasonal tropical climates (e.g., SDTFs) must be so well adapted to extremely drought-prone conditions that they can persist for millions of years as geographically restricted populations.

\section{MATERIALS AND METHODS}

Taxon Sampling—Sampling DNA sequence variation focused on multiple conspecific accessions of nearly all species and infraspecific taxa in Robinieae by expanding the studies of Lavin et al. (2003), Duno-de-Stefano et al. (2010), Queiroz and Lavin (2011), Pennington et al. (2011), and Pennington and Lavin (2016). Of the 77 species in the tribe, we sampled 73 species with 478 accessions in total and most species represented by multiple samples (Table 1). The 
four yet-unsampled species of Robinieae (listed in Table 1) are represented by just type collections, of which leaf extractions yielded unamplifiable DNA. Field specimens of these four have not been successfully located. We sampled 85 accessions representing all eight taxonomic varieties of Coursetia caribaea: vars. caribaea, astragalina, chiapensis, ochroleuca, pacifica, sericea, tomentosa, and trifoliolata (Lavin 1988; Lavin and Sousa 1995). The designated outgroup included 10 species and 11 accessions from the tribes Loteae and Sesbanieae, following Lavin et al. (2003). Sampling occurred primarily from herbarium specimens and included nearly the full extent of the ecological, geographical, morphological, and taxonomic variation of both tribe Robinieae and Coursetia caribaea. Geographic coordinates (longitude and latitude in decimal degrees and mapped with the coordinate reference system + proj $=$ longlat + datum $=$ WGS84) for all samples were taken from herbarium label data and verified using knowledge of the collection area and the geographic mapping functions in the dismo and raster packages (Hijmans et al. 2016; Hijmans et al. 2017) of the program R (R Core Team 2017). Herbarium specimens sampled during this study came from ASU, CICY, E, F, FHO, HUEFS, HUH, K, MEXU, MICH, MO, MONT, NY, and US (acronyms follow Thiers 2017).

DNA Sequence Data and Phylogenetic Analysis-Total genomic DNA came from leaf tissue using the Qiagen DNeasy plant mini kit (Valencia, California). The nrDNA ITS region (Baldwin et al. 1995; Song et al. 2012), subjected to comprehensive sampling within and among species of Robinieae, shows high levels of intra- and inter-specific geographic variation (e.g., Duno-deStefano et al. 2010; Queiroz and Lavin 2011; Pennington et al. 2011; Pennington and Lavin 2016). The nrDNA ITS region readily amplified from leaf extractions of herbarium specimens with a great range in age (e.g., some specimens were over 100 years old) and stored under highly variable conditions (e.g., from herbaria located in tropical and temperate regions). Analyzing 
chloroplast DNA sequences from the phylogenetically informative $\operatorname{trnD}$-trnT region (Pennington et al. 2011; Queiroz and Lavin 2011) verified relevant results from the nrDNA ITS analysis. Amplification and sequencing primers and reaction conditions for the nrDNA ITS region were described in Lavin et al. (2003) and those for the $\operatorname{trnD}$-trnT region were described in Shaw et al. (2005). We minimized the potential cross contamination of conspecific samples by isolating and amplifying DNA of conspecific samples during different time periods separated by months or years.

Assembly of forward and reverse sequence reads into contigs used Sequencher 4.1 (Gene Codes, Ann Arbor, Michigan). MUSCLE alignments included default parameters and several rounds of refinements (Edgar 2004). Manual alignments and other data manipulations involved PhyDE (Müller et al. 2010). The phylogeny figures in this study report all GenBank accession numbers, many of which were reported previously (Lavin et al. 2003; Duno-de-Stefano et al. 2010; Queiroz and Lavin 2011). All GenBank accessions include recently updated collection locality information (e.g., https://www.ncbi.nlm.nih.gov/nuccore/GQ996241), including latitude and longitude. The nrDNA ITS and trnD-trnT data matrices, along with command blocks, have been deposited in TreeBASE (study 18275) and Dryad (datadryad.org; Lavin et al. 2018).

With direct sequencing, we failed to detect paralogous nrDNA ITS sequences (e.g., Bailey et al. 2003; Song et al. 2012). To favor paralog detection, we PCR amplified samples for 40 cycles, each annealing primers at $48^{\circ} \mathrm{C}$ for $1 \mathrm{~min}$ followed by an extension for $10 \mathrm{~min}$. Contig assembly of forward and reverse reads, sequence data alignments, and Bayesian parameter estimation of base frequencies, substitution rates, and invariant sites revealed no anomalous ITS1, 5.8S, and ITS2 sequences. 
Parsimony analyses involved PAUP* 4.0a build 159 (Swofford 2002). Heuristic searches included setting the number of random addition replicates at 100, holding 10 trees at each step, using tree-bisection-reconnection branch swapping on non-minimum trees, and ultimately retaining a maximum of 10,000 most parsimonious trees. Nonparametric bootstrap resampling (Felsenstein 1985) included 10,000 replicates each subjected to the same heuristic search options but with no retention of multiple trees per bootstrap replicate.

Bayesian analyses (Yang and Rannala 1997) used MrBayes 3.2.6 (Huelsenbeck and Ronquist 2001; Ronquist and Huelsenbeck 2003). This included estimating all nucleotide frequency and substitution variables separately for each data partitions (i.e., the nrDNA ITS1, 5.8S, and ITS2 regions, and the $\operatorname{trn} D$-trn $Y, \operatorname{trn} Y$-trnE, and $\operatorname{trn} E$-trnD regions). All analyses involved two separate runs of a Metropolis-coupled Markov chain Monte Carlo permutation of variables with each run initiated using a random tree and four chains set at default temperatures. Information criteria implemented in jModeltest2 (Guindon and Gascuel 2003; Darriba et al. 2012) enabled selection of the nucleotide substitution model GTR $+\mathrm{I}+\mathrm{G}$ for both the nrDNA ITS and the $\operatorname{trn} D$-trnT regions. Markov chains were run for $20 \times 10^{6}$ generations and sampled every $20 \times 10^{4}$ generation. Burnin involved discarding the first $25 \%$ of the samples from each run (i.e., the default). The default settings of the 'sump' command in MrBayes verified likelihood stationarity and convergence of the two separate runs.

Evolutionary Rates Analysis-Estimates of nucleotide substitution rates and ages involved the program r8s (Sanderson 2012), as described in Lavin et al. (2005), and the chronos function in the ape package (Paradis et al. 2004; Paradis 2013 and 2017) of the program R (R Core Team 2016). Absolute rates and ages were obtained by constraining the age of the Robinieae crown

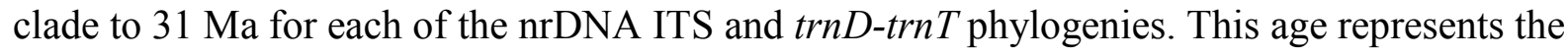


minimum estimated by Lavin et al. (2005) for the crown clade of the Robinieae phylogeny (node 74). By using this minimum age constraint, we wanted to determine if we could still obtain old age estimates after biasing for young ages (cf., Lavin et al. 2005). Age and rate estimates derived from penalized likelihood (PL) rate smoothing (Sanderson 2002) come from the mean and standard deviation of 100 Bayesian trees.

\section{RESUlTS}

The nrDNA ITS data set of 489 aligned sequences included 777 nucleotide sites. The trnD$\operatorname{trn} T$ data set of 186 sequences included 2143 aligned sites. The combined nrDNA ITS and $\operatorname{trn} D$ trnT data set comprised 181 sequences and 2799 aligned sites (763 nrDNA ITS and 2036 trnDtrnT sites). The larger number of nrDNA ITS samples results from this region being amplified much more readily than chloroplast loci from DNA isolations of small leaf fragments of herbarium specimens. The nrDNA ITS data set included $0.1 \%$ missing entries, the $\operatorname{trn} D$-trnT data sets $1.2 \%$ missing entries, and the combined data set $0.4 \%$ missing entries. Missing data comprised mostly small regions of leading and trailing sequences. Parsimony analysis of the nrDNA ITS data set identified 431 informative sites that resolved a set of 10,000 most parsimonious trees each with a length of 2167 steps, a consistency index of 0.412 and a retention index of 0.948 . Parsimony analysis of the trnD-trnT data set identified 504 informative sites that resolved a set of 10,000 most parsimonious trees each with a length of 1226 steps, a consistency index of 0.749 and a retention index of 0.937 . Parsimony analysis of the combined data identified 755 informative sites that resolved a set of 10,000 most parsimonious trees each with a length of 2557 steps, a consistency index of 0.583 and a retention index of 0.920 . 
Parsimony and Bayesian analyses of the nrDNA ITS and trnD-trnT resolved the same general relationships with respect to well-supported clades (i.e., those with both $\geq 90$ parsimony bootstrap percentages and $\geq 0.95$ posterior probabilities). This was especially the case regarding Coursetia caribaea vars. astragalina, ochroleuca, and pacifica. Multiple samples of each of these three varieties formed clades that did not nest within the clade containing samples of Coursetia caribaea var. caribaea (Figs. 1-2; Figs. S1-3). In contrast, the clade containing all samples of Coursetia caribaea var. caribaea also included those of C. caribaea vars. chiapensis, sericea, tomentosa, and trifoliolata, as well as certain other species, such as Coursetia andina, $C$. barancana, C. glabella, C. greenmanii, C. guatemalensis, C. hidalgoana, and C. pumila (Figs. S1-3). These similar results from separate data analyses prompted the combined analysis.

The analysis of the nrDNA ITS and combined data resolved Coursetia caribaea var. astragalina as sister to the Coursetia grandiflora clade, which comprises C. gracilis, C. dubia, and C. grandiflora (Figs. 1-2, 3a). The trnD-trnT phylogeny resolved Coursetia caribaea var. astragalina as sister to a clade comprising a subset of samples of $C$. hassleri from Bolivia and northern Argentina, but this relationship was poorly by parsimony bootstrap analysis (Fig. S2). Regardless, in all analyses, var. astragalina is not most closely related to samples of var. caribaea. All analyses resolved Coursetia caribaea var. ochroleuca (centered in Ecuador and Peru) as sister to the clade of the samples of Coursetia caribaea var. pacifica (coastal Oaxaca, Mexico; Figs. 1-2, 3b). Furthermore, in all analyses, the clade containing samples of vars. ochroleuca and pacifica was not resolved as most closely related to the clade with samples of var. caribaea.

The mean ages estimated from nrDNA ITS data for the stem clades of vars. astragalina, pacifica, and ochroleuca were 11, 7.7, 7.7 Ma, respectively (Table 2). These contrast to mean 
ages estimated for the respective crown clades of 0,0 , and 1.5 Ma. These stem age estimates are generally older than those of clades resolved for three of the five remaining varieties of Coursetia caribaea, vars. sericea, tomentosa, and trifoliolata (Table 2; var. chiapensis was not resolved as monophyletic and var. caribaea was resolved as paraphyletic with respect to a subset of Coursetia species; Fig. S1). The mean ages estimated from the trnD-trnT data for the stem clades of vars. astragalina, pacifica, and ochroleuca were 4.2, 2.9, and 2.9 Ma, respectively (Table 3 ). These contrast to mean ages estimated for the respective crown clades of 0,0 , and 0.3 Ma. The two geographically restricted Coursetia caribaea vars. astragalina and pacifica (Figs. $3 a, b$, respectively) each lacked intravarietal sequence diversity and thus associated with a young crown age estimate. The geographically widespread var. ochroleuca (Fig. 3b) harbored greater sequence diversity resulting in its older crown age estimates (Tables 2-3).

\section{DISCUSSION}

The nrDNA ITS, trnD-trnT, and combined phylogenies each resolved highly supported clades of conspecific samples for each of Coursetia caribaea vars. astragalina, ochroleuca, and pacifica. These clades were each distantly related to samples of the other varieties of $C$. caribaea (Figs. 1-2). This congruence provides the prima facie evidence for ranking these three varieties at the species level. Samples of Coursetia caribaea vars. chiapensis, sericea, trifoliolata, and tomentosa derive from the clade containing the samples of var. caribaea (Fig. S1). Ranking these four varieties at the species level, as in the case of Coursetia greenmanii (Duno-de-Stefano et al. 2010), remains in question pending a comprehensive sampling of DNA sequence variation, in addition to a detailed geographic and morphological analysis. 
Ranking Coursetia caribaea vars. astragalina, ochroleuca, and pacifica at the species level also is justified by the congruence of morphological, geographical, and molecular phylogenetic evidence. The phenotypic distinctions reported in Lavin (1988) and reiterated in the Taxonomic Section, below, support the morphological integrity of these three taxa. The limited geographic distribution of each of these three in localized regions of SDTF, which is typical of species endemic to this biome (e.g., Pennington et al. 2006 and 2009; Duno-de-Stefano et al. 2010; Pennington et al. 2011; Queiroz and Lavin 2011; Pennington and Lavin 2016), evinces the geographical integrity of these three taxa. Coursetia caribaea var. astragalina occurs in southwestern Colombia in the provinces of Nariño and Valle del Cauca (Fig. 3a). Coursetia caribaea var. ochroleuca inhabits coastal and inter-Andean SDTF in Ecuador, Peru, and the Yungas region of Bolivia. Coursetia caribaea var. pacifica resides in a small region of SDTF from southern Oaxaca, Mexico (Fig. 3b). The phylogenetic integrity of these three is evinced by samples of DNA sequences from accessions of each of vars. astragalina, ochroleuca, and pacifica forming coalesced clades with old stem ages in both the nrDNA ITS and trnD-trnT analyses (Tables 2-3).

This study reveals other lineages that potentially deserve ranking at the species level. Examples include two of the five remaining varieties of Coursetia caribaea, var. sericea from Arizona and northern Mexico and var. trifoliolata from west-central Mexico. Also included here are two clades of Coursetia glandulosa from the northern and southern Sierra Madre Occidental, and the northeastern and southwestern clades of Coursetia hassleri centered in northern Argentina and adjacent countries (Figs. S1-S3). These clades need more study, which could reveal whether they each have ecological, genetic, geographical, and morphological integrity. 
The discovery of overlooked species diversity in Coursetia parallels the results from recent densely sampled phylogenies of other Neotropical SDTF legume genera, including Poissonia (Pennington et al. 2011), Mimosa (Särkinen et al. 2011), Leucaena (Govindarajulu et al. 2011), and Arquita (Gagnon et al. 2015), all of which have revealed similar deeply coalescent, reciprocally monophyletic clades representing previously unrecognized species. This suggests that with the construction of phylogenies with complete sampling of species and dense sampling of intraspecific diversity for other SDTF genera, additional species with narrowly restricted distributions endemic to single SDTF nuclei can be expected (Pennington and Lavin 2016). This would further highlight the striking patterns of high phylogenetic $\beta$-diversity, endemism, and geographical phylogenetic structure across the SDTF biome (DRYFLOR 2016).

The old age estimates of the stem clades and the young age estimates of the crown clades (Tables 2-3), interpreted by coalescent theory (e.g., Naciri and Linder 2015), suggest that Coursetia caribaea vars. astragalina, ochroleuca, and pacifica each have inhabited their respective areas for at least several million years in isolation as small populations (Pennington and Lavin 2016). These taxa must be well adapted to the low and erratic moisture regime of the SDTF biome so that they can persist as separately evolving metapopulations with small effective sizes in narrow geographic confines and without ecological interference by immigration of species not likely to be as adapted to SDTFs (Pennington et al. 2009; Pennington and Lavin 2016). The three focal taxa are ecologically similar with respect to inhabiting mainly coastal or Pacific slope SDTFs. However, the phenotypic, geographic, and phylogenetic integrity of each of Coursetia caribaea vars. astragalina, ochroleuca, and pacifica suggests that they each have been separately evolving lineages for millions of years. Therefore, they meet the criteria of a lineagebased species concept (e.g., de Queiroz 2007) and warrant recognition at the species level. 


\section{TAXONOMIC TREATMENT}

The following key distinguishes the newly ranked species from all similar taxa. It derives from Lavin (1988) and Duno-de-Stefano et al. (2010) and includes five remaining varieties of Coursetia caribaea and all species morphologically like C. caribaea. The morphological distinction of this group of species in the context of the genus Coursetia delimited by Lavin (1988) and Lavin et al. (2003), includes the following: growth habit of subshrubs and herbs, rarely large shrubs and treelets; leaves imparipinnate, leaflets sometimes with reticulate purplish tannin blotches on the abaxial surfaces of herbarium (pressed and dried) specimens, stipules not spinescent, leaf rachis eglandular; inflorescences erect to ascending, solitary in the axils of mature leaves on long shoots, long-pedunculate, peduncles one-third to one-half the length of the rachis, rachis of inflorescence eglandular to occasionally stipitate-glandular; legumes resupinate, falcate-secund, borne from twisted, deflexed pedicels; valves with evident squarish seed compartments.

\section{Key to Coursetia CARIBAEA AND MORPHOlOGiCALly Similar SPECIES}

A. Stems prostrate to decumbent, herbaceous at the base, arising from a woody caudex; abaxial leaflet surfaces with purplish tannin deposits (absent in forms of C. caribaea); roots fusiformtuberous (except in forms of C. caribaea); southwestern USA, Mexico and Central America ...

1. Ovary villous; legume strigose to pilose; banner petal yellowish; tannins deposited only along veins of abaxial leaflet surfaces; montane pine-oak settings in the southwestern USA (Arizona) and adjacent Mexico (Chihuahua) C. glabella 
1. Ovary granuliferous; legume glabrous; banner petal whitish to pink or yellow; tannins, if present, deposited on abaxial leaflet surface 2.

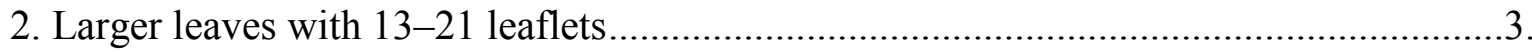

3. Leaflet tannins, if present, confined toward the center of the abaxial leaflet surface, never extending to the margins; raceme rachis stipitate-glandular to eglandular; terminal leaflet usually larger than the lateral ones; stems ascending at least at the base, roots tuberous or not; Yucatan Peninsula region, or northwestern Mexico (Sonora, western Chihuahua, Baja California Sur) and the adjacent U.S.A. (Arizona), sporadically to southern Mexico. C. caribaea (see couplet 19)

3. Leaflet tannins confined to the margins and midrib, or evenly scattered over the entire abaxial leaflet surface; raceme rachis eglandular; terminal leaflet equal in size to the lateral ones; stems prostrate to decumbent from the base; roots always tuberous; Mexico (extreme southern Chihuahua southward to Oaxaca along the Sierra Madre Occidental, Sierra Madre del Sur, and Sierra Volcánica Transversal). 4.

4. Petals whitish to pinkish, occasionally the banner petal yellowish; calyx tube brownish, strigose to pilose; inflorescence rachis glabrate to sparsely strigose; legume 3-4 mm wide; Mexico (southern Chihuahua south to Oaxaca)....C. pumila 4. Petals all yellowish; calyx tube whitish green, sericeous; inflorescence rachis densely whitish sericeous to villous; legume 4.5-5.0 mm wide; Mexico (Hidalgo, Edo. México) C. hidalgoana 
5. Leaflets 5-9 per leaf, with tannin deposits on both surfaces; inflorescence rachises eglandular, much longer than the subtending leaves; ovary with 25-30 ovules; border of Chihuahua and Sonora, Mexico C. barrancana

5. Leaflets 3-5(-7) per leaf, without tannin deposits, if present, only on the abaxial surface; inflorescence rachis stipitate-glandular to eglandular, equal to or shorter than the subtending leaves (longer in C. caribaea var. sericea but then stipitateglandular); ovary with 15-23 ovules; widespread from northern Mexico to Central America. 6.

6. Leaves with exactly 3 leaflets, the terminal one $2-3$ times longer than the laterals; branches and calyx hispid with dull reddish trichomes; floral bracts 4-10 $\mathrm{mm}$ long, commonly persistent to anthesis; southern coastal Mexico (Oaxaca)

C. diversifolia

6. Leaves with 3-27 leaflets, the terminal one less than twice as long as the laterals; branches glabrate to hispid or lanate, calyx sericeous with whitish trichomes; floral bracts less than $6 \mathrm{~mm}$ long, caducous before anthesis; widespread in Mexico 7.

7. Stems covered with short, closely appressed, whitish trichomes; leaflets 3 or 5 per leaf, venation impressed above; inflorescence rachis eglandular; roots cylindrical fusiform-tuberous C. caribaea var. trifoliolata

7. Stems sericeous to hispid with long, widely spreading trichomes, occasionally lanate; leaflets usually 5 or more per leaf, venation not impressed above; inflorescence rachis mostly stipitate-glandular; roots not tuberous, or spheroidal fusiform-tuberous 8. 
8. Prostrate herbs even in undisturbed settings; roots with fusiform tubers; leaves with petiole $15-39 \mathrm{~mm}$ long, total length $63-98 \mathrm{~mm}$, with 3-5(-7) leaflets, distal leaflets abruptly accrescent and mostly widely elliptic; leaflet vestiture of short appressed hairs on the lower surface, and upper leaf surface glabrous; peduncle of inflorescence 20-110 mm long; rachis with 4-5 flowers, eglandular; Yucatan Peninsula C. greenmanii

8. Erect subshrub or prostrate if growing in disturbed settings; roots with a lignified main axis (uniformly so in the Yucatan Peninsula) or with tubers (in northwestern Mexico and adjacent U.S.A.); leaves with petiole 3-10 mm long, total length 35-95 mm, with 9-27 leaflets, distal leaflets moderately accrescent, if at all, and mostly narrowly elliptic; leaflet vestiture of long appressed hairs at least on lower surface; peduncle of inflorescence generally less than $20 \mathrm{~mm}$ long; rachis with 1-2(-4) flowers, or, if with more, the rachis stipitate-glandular; widespread

C. caribaea (see couplet 20)

A. Stems erect to ascending (often decumbent in C. gracilis), woody at the base, arising from a stout woody rootstock; abaxial leaflet surface without purplish tannin deposits (except $C$. caribaea vars. sericea and tomentosa), roots not fusiform-tuberous (except C. caribaea var.

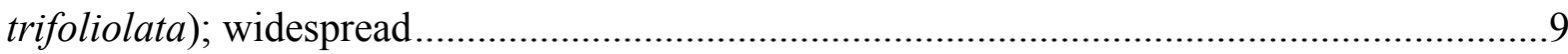

9. Leaves with the terminal leaflet conspicuously the largest; stipels well-developed.............10.

10. Banner petal deep red, striate with purplish veins; flowers densely clustered on a rachis, internodes 1-2 $\mathrm{mm}$ long and reddish brown hispid; abaxial leaflet surfaces 
without tannin deposits; mountains of western Guatemala and adjacent Mexico (Chiapas) C. guatemalensis

10. Banner petal whitish to pinkish, or yellowish, striate with reddish veins; flowers not densely clustered on a rachis, internodes mostly more than $3 \mathrm{~mm}$ long and rarely hispid; abaxial leaflet surfaces with tannin deposits (in C. caribaea vars. sericea and tomentosa) or without; widespread C. caribaea (see couplet 17)

9. Leaves with all leaflets about equal in size or gradually reduced distally; stipels absent or present 11.

11. Calyx lobes triangular, mostly shorter than the tube (often longer in C. weberbaueri); staminal tube arched, pseudomonadelphous (the vexillary filament adnate near the base); ovary glabrous to granuliferous; style with an extrorse pollen brush densely compacted toward the distal end; Ecuador and Peru

12. Largest leaflets $20-31 \mathrm{~mm}$ long, 5-10 mm wide, abaxial surface glabrate to sparsely strigose; banner petal 17-18 mm long; largely unbranched shrubs to $4 \mathrm{~m}$ tall; Peru (Tumbes) C. tumbezensis

12. Largest leaflets 4-23 mm long, 1-6.5 mm wide, abaxial surface densely sericeous to woolly; banner petal 9-15 mm long; much branched shrubs to $2 \mathrm{~m}$ tall; Ecuador, interior northern Peru. 13. 13. Banner petal dark red to rose, 9-10 mm long; ovary with 14-18 ovules; style 6-7 mm long; pedicel 2.0-2.5 mm long; leaflets 4-11(-14) mm long, (37-)41-51 per leaf; Ecuador C. dubia 
13. Banner petal whitish to purple, 11-15 mm long; ovary with 18-22 ovules; style 8-10 mm long; pedicel 2.5-6.0 mm long; leaflets 5-23 mm long, 21-43 per leaf; northern Peru, southern Ecuador. C. grandiflora

11. Calyx lobes narrowly to broadly lanceolate or narrowly triangular, usually longer than the tube; staminal tube straight, diadelphous; ovary glabrous to granuliferous or villous to woolly; style with a latrorse pollen brush loosely scattered along nearly the entire length; Mexico, Central America, and South America 14.

14. Leaflets caducous from the leaf rachis, very narrowly elliptic, 5-10 mm long, 1-2 mm wide, apex acute; petals ochroleucus; keel longer than the wings; ovary granuliferous; very small, often decumbent subshrubs with vine-like stems; northern Ecuador . C. gracilis

14. Leaflets persistent on leaf rachis, narrowly elliptic, the larger 8-74 mm long, 3-38 mm wide, apex rounded to acuminate; petals white to pinkish or yellow; keel equal to or shorter than the wings; ovary sericeous to villous or woolly, or rarely granuliferous; erect to ascending shrubs and subshrubs, rarely trees..... 15. 15. Petals evenly yellow, banner petal not striate; leaflets $15-25$ per leaf, gradually reduced in size towards the apex; stipels absent; ovary densely villous.

16. Raceme rachises 6-17 cm long, well exserted above the leaves; pedicel, calyx, and/or raceme rachis stipitate glandular; leaflets 21-25 per leaf; branches sericeous; Colombia (Boyacá) C. intermontana

16. Raceme rachises $1-4 \mathrm{~cm}$ long, congested among leaves at distal branch ends; pedicel, calyx, and raceme rachis eglandular; leaflets 15-23 per leaf; branches densely villous; Venezuela (Mérida) C. andina 
15. Petals whitish to pinkish or yellowish, banner petal often striate, the veins suffused with red; leaflets 5-27 per leaf, uniform in size or gradually enlarged toward the apex; stipels usually present; ovary woolly (in C. astragalina), villous, granuliferous, stipitate-glandular, or glabrous . 17. 17. Abaxial leaflet surfaces purplish, at least in part, with tannin deposits; subshrubs and herbs; U.S.A., Mexico, and Central America 18.

18. Branches and abaxial leaflet surfaces densely sericeous to tomentose; leaflets 5-7 per leaf, widely elliptic; all petals yellow; Mexico (Hidalgo and San Luis Potosí) C. caribaea var. tomentosa

18. Branches sericeous to hispid or glabrous; abaxial leaflet surfaces pilose to densely sericeous; largest leaves with more than 7 narrowly to widely elliptic leaflets; all petals whitish, or only the banner petal yellowish and commonly suffused with red along veins....... 19. 19. Erect to ascending subshrubs, rarely herbs; inflorescence rachis $1.5-3.5$ times the length of the subtending leaf, with up to 30 nodes; abaxial surface of leaflets with purplish tannin deposits in the center of the lamina; Mexico (northern Sinaloa and Durango, Sonora, and Chihuahua) and the adjacent U.S.A. (Arizona) C. caribaea var. sericea

19. Decumbent herbs and weak subshrubs; inflorescence rachis much less than 1.5 times the length of the subtending leaf, with fewer than 16 nodes; abaxial surface of leaflets usually without tannin deposits, but if so, then evenly scattered; widespread in Mexico and Central America...... 
17. Abaxial leaflet surfaces without purplish tannin deposits; trees, shrubs, and subshrubs; West Indies, Mexico, Central America, and South America.

20. Ovary and sometimes developing legume stipitate-glandular; calyx lobes 7-9 $\mathrm{mm}$, as long or longer than the keel petals; largest leaves with 21-27 narrowly elliptic leaflets; Mexico (western Chiapas and adjacent Oaxaca) ....

\section{C. caribaea var. chiapensis}

20. Ovary granuliferous to villous or woolly, developing legume eglandular; calyx lobes less than $7 \mathrm{~mm}$, shorter than the keel petals but if longer then leaves with fewer than 15 leaflets; largest leaves with 5-21(-25) narrowly to widely elliptic leaflets

21. Petals whitish to yellow; inflorescence with internodes mostly $\geq 3 \mathrm{~mm}$ long; leaves with (9-)13-21(-25) narrowly to widely elliptic leaflets; ovary villous to woolly, rarely granuliferous; legume villous to woolly, rarely glabrous

22. Pedicels 5-8 mm long at anthesis; calyx attenuate at base; ovary woolly, with 17 or 18 ovules; legume 5-7 mm wide; inflorescence rachis eglandular; Colombia (Valle del Cauca and Nariño)

C. astragalina

22. Pedicels $2-4 \mathrm{~mm}$ long at anthesis; calyx rounded at base; ovary villous to granuliferous, with $22-30$ ovules; legume $2.5-4.0 \mathrm{~mm}$ wide; inflorescence rachis stipitate glandular, rarely eglandular; widespread C. caribaea var. caribaea 
21. Petals yellow; inflorescence with internodes mostly $<3 \mathrm{~mm}$ long; leaves with 5-7(-9) widely-elliptic leaflets; ovaries granuliferous; legume glabrous; coastal Ecuador and Peru, and northern Bolivia

C. ochroleuca

Coursetia astragalina (Kunth) Lavin, comb. nov. Tephrosia astragalina Kunth, Nov. Gen. Sp. (quarto ed.) 6: 464-465. 1823. Cracca astragalina (Kunth) Kuntze, Revis. gen. sp. 1: 174. 1891. Coursetia caribaea var. astragalina (Kunth) Lavin, Syst. Bot. Monogr. 21: 129, 1988. Type: Ecuador. ChimBorazo: Penipe, Jul 1802 (fide Sandwith 1925) Humboldt \& Bonpland s. n. (holotype: P-HBK, microfiche IDC 6209.165:I.1, photo P00660155 at https://explore.recolnat.org/search/botanique/simplequery=tephrosia\%2520astragalina).

Small trees and shrubs mostly 2-3 m tall. Stems erect; branches hispid. Root system unknown. Leaflets 17-23 per leaf, 15-27 mm long, 7-11 mm wide, elliptic, both surfaces sericeous, without tannin deposits, venation not impressed above. Inflorescence rachis $3-10 \mathrm{~cm}$ long, equaling the subtending leaf, with up to 25 nodes, internodes about $3 \mathrm{~mm}$ long, hispid, eglandular; floral bracts 3-4 mm long, caducous; pedicels 5-8 $\mathrm{mm}$ long at anthesis. Calyx attenuate at base, sericeous, lobes 3-4 mm long, narrowly lanceolate. Banner petal 11-12 mm long, whitish; wings 11-12 mm long, whitish; keel 11-12 mm long, whitish. Ovary woolly, with 17-18 ovules. Legume 5-7 mm wide, villous to woolly.

Phenology —Flowering sporadically from February through September, fruiting specimens from September.

Distribution-Known from SDTFs of the southern Colombian provinces of Nariño and Valle del Cauca, and perhaps disjunct in the province of Chimborazo, Ecuador, the putative type 
locality (Fig. 3a; see Lavin 1988); mostly 1000-1900 m but two specimens come from 600-800 m. Label data report the habitat to be dry streambeds and generally disturbed settings. Additional Specimens Examined—( ${ }^{1} \mathrm{TS},{ }^{2} \operatorname{trn} D-\operatorname{trn} T$ GenBank accession). Colombia. NARIÑO: Río Guaitara, 1.057197 N, 77.448272 W, André 3188 (F, GH, NY, US), ${ }^{1} \mathrm{KX} 235187$; Carr. Panamerican, Pasto, Puente Juanambú, 1.514761 N, 77.310419 W, Benavides 3657 (NY), ${ }^{1} \mathrm{KX} 235193,{ }^{2} \mathrm{KX} 235222$; Alto de Bomboná, Consacá, 1.202215 N, 77.447204 W, Benavides 5161 (NY), ${ }^{1} \mathrm{KX} 235190,{ }^{2} \mathrm{KX} 235220$; Yacuanquer, Minda, Garganta 527 (F); Consacá. Corregimiento de Bomboná, 1.202215 N, 77.447204 W, Ramírez 953 (NY), ${ }^{1}$ KX235192, ${ }^{2}$ KX235221; Río Guaitara, Pasto, Triana 4260 (NY, US), ${ }^{1}$ KX235191. Valle del CaUCA: Cordillera Occidental, La Cumbre, Cuatrecasas 19624 (F); Hacienda Valparaíso, Dryander 2159 (US); Espinal, below Dagua, Killip \& Hazen 11083 (GH, NY, US), ${ }^{1}$ KX235189; Río Dagua. Forests of Cali, 3.634125 N, 76.670108 W, “B. T.” 1165 [possibly B. T. Lehman] (NY), ${ }^{1} \mathrm{KX} 235188$.

Taxonomic Comments-Coursetia astragalina is like C. ochroleuca in its inflorescence with numerous apically congested flower buds and a densely hispid stem and leaf vestiture. It differs from C. ochroleuca and C. caribaea by the combination of its pedicels that measure 5-8 $\mathrm{mm}$ long, legumes 5-7 mm wide, young stems that are densely hispid, and an occasional treelet habit. Correlated with these features are several other characters that are variable in Coursetia ochroleuca and C. caribaea but almost invariable in C. astragalina: 17-23 uniformly sized leaflets per leaf that are equally sericeous on both surfaces, banner petal whitish, and 11-12 mm long, calyx tubes narrowly campanulate and attenuate at base, calyx lobes narrowly lanceolate, and ovaries woolly. 


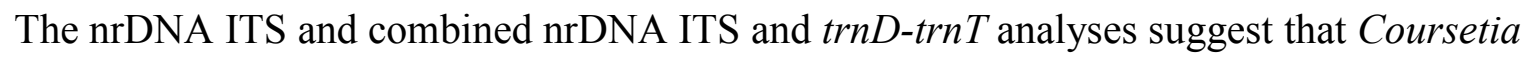
astragalina is sister to the rest of the Coursetia grandiflora clade (Figs. 1-2, Fig. S1).

Geographically, this makes sense because Coursetia astragalina is distributed just to the north of the other four species of the Coursetia grandiflora clade in the seasonally dry forests of the northern and central Andes, and branching order (Fig. 1; the Coursetia grandiflora clade) follows the north to south distribution (Fig. 3a). However, morphology is not strongly suggestive of this relationship (see above key to species). The only hint of a relationship with the Coursetia grandiflora clade involves the leaves of $C$. astragalina with leaflets that are not distally accrescent. Rather, they are relatively numerous (17-23 per leaf), uniformly sized, and elliptic in outline, like the leaves and leaflets produced by the rest of the Coursetia grandiflora clade. The distal leaflets of the leaves of C. caribaea and closely related species, in contrast, tend to develop leaves with fewer leaflets and a conspicuously larger length and width of the terminal leaflets compared to the medially and basally positioned leaflets.

Coursetia diversifolia (Liebm.) M.Sousa \& Lavin, comb. nov. Balboa diversifolia Liebm., Vidensk. Meddel. Dansk Naturhist. Foren. Kjøbenhavn 1853: 106. 1854, non Cracca diversifolia Rose, 1909. Cracca pacifica M.Sousa \& Lavin, nom. nov., Brittonia 38: 302. 1986. Coursetia caribaea (Jacq.) Lavin var. pacifica (M.Sousa \& Lavin) Lavin, Syst. Bot. Monogr. 21: 128, 1988.TYPE: Mexico. OAXACA: inter Chacalapa et S. Jago Estata [Santiago Astata], Nov 1842, Liebmann 4626 (holotype: C!; isotype: US!).

Subshrubs and shrubs 30-80 $\mathrm{cm}$ tall. Stems erect to ascending; branches hispid with dull reddish trichomes. Root system unknown. Leaflets 3 per leaf, 31-100 mm long, 17-50 mm wide, the terminal one (60-100 $\mathrm{mm}$ long, $30-50 \mathrm{~mm}$ wide) $2-3$ times longer than the lateral leaflets, 
elliptic, glabrous and glossy to sparsely strigose above, pilose beneath, tannin deposits absent, venation not impressed above. Inflorescence rachis $2-4 \mathrm{~cm}$ long, shorter than the subtending leaf, with up to 20 nodes, internodes more than $3 \mathrm{~mm}$ long, hispid with reddish trichomes, eglandular; floral bracts 4-10 mm long, often persistent; pedicels $1.5-2.0 \mathrm{~mm}$ long at anthesis. Calyx rounded at base, hispid, lobes 3-4 mm long, lanceolate. Banner petal 7-8 mm long, 8-9 $\mathrm{mm}$ wide, yellow, veins suffused with red; wings $7.0-7.5 \mathrm{~mm}$ long, yellow; keel 7-8 $\mathrm{mm}$ long, yellow. Ovary granuliferous, with $15-16$ ovules. Legumes up to $6.0 \mathrm{~cm}$ long, ca. $5 \mathrm{~mm}$ wide, valves glabrous, reticulate-veined, brown, elastically dehiscent. Seeds $2-3 \mathrm{~mm}$ diam., brown.

Phenology—Flowering specimens were collected during September, November, and December, and fruiting specimens from April and June. Perhaps flowering and fruiting sporadically throughout the year.

Distribution-Coursetia diversifolia is known from SDTFs near the coast of southern Oaxaca, Mexico (Fig. 3b); 30-400 m.

Additional Specimens Examined—( ${ }^{1} \mathrm{TS},{ }^{2}$ trnD-trnT GenBank accession). Mexico. OAXACA: Distrito Pochutla. Mpio. San Miguel del Puerto, Puente Zimatán, 7.8 km al N hacia Santa María Xadani, 15.878334, 96.022203, Rivera 2310 (MEXU); Dist. Pochutla. Mpio. San Miguel del Puerto, 15.87 N, 96.03 W, Saynes 2314 (MEXU), ${ }^{1}$ KT281087, ${ }^{2}$ KP990786; Dist. Tehuantepec. Mpio. Santiago Astata, El Chorro, 15.99 N, 95.67 W, Castrejón 563 (MEXU), ${ }^{1}$ KT281086; Dist. Tehuantepec. Mpio. San Pedro Huamelula, camino a Chacalapa, $2.4 \mathrm{~km}$ al N de la carretera costera, $450 \mathrm{~m}$ al E de la brecha. 15.890022 N, $95.926101 \mathrm{~W}$, Rivera 2354 (MEXU); Distrito Tehuantepec. Mpio. San Pedro Huamelula, San Isidro Chacalapa, 7 km al Sur, 15.891962, 95.922203, Salas 2897 (MEXU); Dist. Tehuantepec. Mpio. San Pedro Huamelula, 16.03 N, 95.67 W, Salas 3625 (MEXU), ${ }^{1}$ KT281088, ${ }^{2}$ KP990788; Dist. Tehuantepec. Mpio. Santiago 
Astata, Chacapala, 15.92 N, 95.92 W, Saynes 2809 (MEXU), ${ }^{1}$ GQ996224, ${ }^{2}$ KP990785; Dist. Yautepec. 11 km N Ayutla, 15.91 N, 95.85 W, Martínez 33249 (MEXU), ${ }^{1}$ KT281089, ${ }^{2} \mathrm{KP} 990787$.

Taxonomic Comments-Coursetia diversifolia is perhaps sympatric with C. caribaea var. caribaea in southern Oaxaca but collections of both taxa from the same locality are yet unknown. Morphologically, C. diversifolia is like C. caribaea var. trifoliolata in that both have leaves with exactly three leaflets and ovaries with relatively few ovules (15-16). However, $C$. diversifolia differs in having a terminal leaflet $2-3$ times as long or longer than the lateral two leaflets, subulate stipules up to $10 \mathrm{~mm}$ long, mostly persistent floral bracts, and calyces and inflorescence rachises densely reddish to silvery hispid (Sousa and Lavin 1986). Coursetia diversifolia shares the last two features with $C$. guatemalensis. Aside from the large terminal leaflet of the trifoliolate leaf, the persistent axillary inflorescence rachis is also diagnostic of $C$. diversifolia. It measures $2-4 \mathrm{~cm}$ long and is generally silvery hairy and with persistent floral bracts.

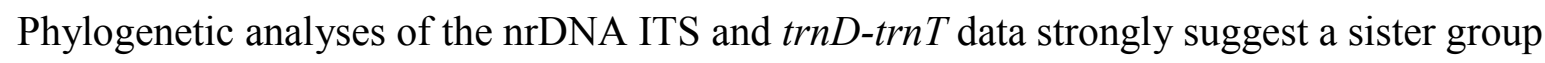
relationship of C. diversifolia and C. ochroleuca (Figs 1-2). These phylogenetic results contrast to both the lack of distinctive morphological similarities shared between these two species and their wide geographical separation (Fig. 3b). Sister species of Coursetia often occupy geographically adjacent regions (e.g., Queiroz and Lavin 2011; Fig. 3a).

Coursetia OChroleuca (Jacq.) J.F.Macbr., Publ. Field Mus. Nat. Hist., Bot. Ser. 13, pt. 3: 389. 1943. Galega ochroleuca Jacq., Icon. Pl. rar. 1: 15, pl. 150. 1787. Benthamantha ochroleuca (Jacq.) Alef., Bonplandia 10: 264. 1862. Tephrosia ochroleuca (Jacq.) Pers., 
Syn. pl. 2: 329. 1807. Cracca ochroleuca (Jacq.) Benth., Vidensk. Meddel. Dansk.

Naturhist. Foren. Kjøbenhavn 1853: 9. 1854. Brittonamra caribaea (Jacq.) Kuntze var. ochroleuca (Jacq.) Kuntze, Revis. Gen. pl. 1: 165. 1891. Coursetia caribaea (Jacq.) Lavin var. ochroleuca (Jacq.) Lavin, Syst. Bot. Monogr. 21: 128, 1988.TYPE: Cultivated from seed of unknown origin but very likely from coastal Ecuador or Peru (holotype: not located (see Lavin 1988); line drawing with protologue:

http://biodiversitylibrary.org/page/270623).

Tephrosia glabrescens Benth., Bot. Voy. Suphur 81. 1844. Cracca glabrescens (Benth.) Benth., Vidensk. Meddel. Dansk. Naturhist. Foren. Kjøbenhavn 1853: 9. 1854. Benthamantha glabrescens (Benth.) Alef., Bonplandia 10: 264. 1862. Brittonamra caribaea (Jacq.) Kuntze var. glabrescens (Benth.) Kuntze, Revis. Gen. pl. 1: 165. 1891. TYPE: Colombia (probably Ecuador; see Lavin 1988), Sinclair s. $n$. (holotype: K!; photo: F).

Shrubs 0.5-2 m tall. Stems erect; branches hispid. Root system unknown. Leaflets 5-7(-9) per leaf, 11-64 mm long, 6-40 $\mathrm{mm}$ wide, widely elliptic, glabrate above, pilose beneath, with very faint tannin deposits along veins on the adaxial surface, venation not impressed above. Inflorescence rachis 3-10 cm long, equaling or slightly longer than the subtending leaf, with up to 30 nodes, internodes mostly $<3 \mathrm{~mm}$ long, hispid, eglandular; floral bracts $2-5 \mathrm{~mm}$ long, caducous; pedicels $2-3 \mathrm{~mm}$ long at anthesis. Calyx rounded at base, sericeous, lobes $2-5 \mathrm{~mm}$ long, narrowly lanceolate. Banner petal 9-12 mm long, 10-12 mm wide, yellow; wings 10-12 mm long, yellow; keel 10.0-11.5 mm long, yellow. Ovary granuliferous, with 22-30 ovules. Legume 3-4 mm wide, glabrous.

Phenology — Flowering and fruiting specimens come from December through May and September. 
Distribution-Known from coastal and Pacific-slope SDTFs of Ecuador and northern Peru (from Lima northward) and into interior northern Peru along the Río Marañon and southward into west-central Bolivia in the Yungas region (Fig. 3b); disturbed areas along roadsides and cultivated fields, and on steep, rocky slopes; mostly 0-200 but some specimens up to1800 m.

Additional Specimens Examined-( ${ }^{1} \mathrm{ITS},{ }^{2} \operatorname{trn} D-\operatorname{trn} T$ GenBank accession). Bolivia. LA PAZ: Yungas, 16.215987 S, $67.824221 \mathrm{~W}$, Rusby 2355 (F, NY), ${ }^{1} \mathrm{KX} 235218$.

Ecuador. ChIMBORAZO: vicinity of Huigra, Hacienda de Licay, 2.292697 S, 78.987613 W, Rose \& Rose 22621 (GH, NY), ${ }^{1} \mathrm{KX} 235215$. ESMERALDAS: W side of Esmeraldas, Hudson 709 (MO); $1.5 \mathrm{~km} \mathrm{~S}$ of Esmeraldas, $0.936732 \mathrm{~N}, 79.654807 \mathrm{~W}$, Hudson 758 (MO). GUAYAS: $1 \mathrm{~km} \mathrm{~S}$ of Recinto Olon, Gentry 10030 (MO); Guayaquil, 2.183765 S, 79.951295 W, Pavón s. n. (G). LoJA: La Forma, Espinosa 505 (US); 2 Km W Tambo Negro on Macará-Sozoranga Rd, 4.382974 S, 79.866893 W, Kessler 2706 (NY), ${ }^{1}$ KX235214. MANABí: El Recreo, 0.979561 S, 80.662733, Eggers 15065 (F), 15490 (F, GH, NY), ${ }^{1} \mathrm{KX} 235217$; roadside near Jipipapa, 1.363028 S, 80.607371 W, Haught 3391 (F, NY), ${ }^{1} \mathrm{KX} 235216$; Km 6 Machalilla-Puerto Cayo, 1.435631 S, 80.754306 W, Klitgaard 564 (MONT), ${ }^{1}$ AF398847, ${ }^{2}$ KP990789; Portoviejo et Guayaquil, Mille 1981 (F).

Peru. Cajamarca: Yunán, 7.25 S, 79.08 W, Delgado 2100 (MEXU), ${ }^{1}$ KT281085, ${ }^{2}$ KP990791; Magdalena. Amillás antes de Magdalena, carr. Chilete-Magdalena, 7.248928 S, 78.667962 W, Sánchez Vega 2082 (NY), ${ }^{1}$ KX235219; Jaen. past 55 km mark from Jaen to San Ignacio, 5.46 S, 78.83 W, Särkinen 2183 (FHO, MONT), ${ }^{1} \mathrm{KT} 281083,{ }^{2} \mathrm{HQ} 158026$. LA LIBERTAD: 40 km E of Trujillo, 8.018266 S, 78.719478 W, Hudson 1187 (MO); Cementerio de Trujillo, Sánchez 6290 (US). LAMBAYEQUE: Olmos, 5.92 S, 78.55 W, Delgado 2063 (MEXU), ${ }^{1}$ KT281084, ${ }^{2}$ KP990790; alrededores de Reque, 6.854949 S, 79.824387 W, Llatas 386 (MO). 
LiMA: km 56, carretera Lima-Oroya, Ferreyra 11076 (US); valley E of Sayán, Goodspeed 33039 (GH, MO, UC, US); Chosica, 11.921909 S, 76.701995 W, Macbride \& Featherstone 492 (F); Chancay, Ruiz \& Pavón s. n. (F, G).

Taxonomic Comments-Coursetia ochroleuca is most like C. astragalina and shrubby forms of C. caribaea. It is easily distinguished from the former by its yellow flowers, granuliferous ovaries with more than 21 ovules, and leaves with 5-7(-9) leaflets having mostly glabrate adaxial surfaces. From Coursetia caribaea, it is readily separated by the combination of its leaves with 5-7 widely elliptic leaflets with tannins faintly deposited along the veins of the adaxial surface, an eglandular inflorescence rachis with closely spaced nodes, several to many floral buds congested apically on a rachis, granuliferous ovaries, and glabrous legumes. Although some of these features occur independently on individuals of C. caribaea especially from North America, they seem to be consistent and fixed in this unique combination in $C$. ochroleuca. Additionally, the legumes of C. ochroleuca are usually congested along the inflorescence rachis because of the closely spaced nodes. This feature is otherwise found in Coursetia guatemalensis, which is distantly related to C. ochroleuca. As commented under Coursetia astragalina, no morphological evidence suggests a close relationship between $C$. astragalina and C. ochroleuca.

ACKNOWLEDGMENTS - Comments by two anonymous reviewers improved the presentation of this manuscript. This work was supported in part by the USDA National Institute of Food and Agriculture, Hatch project 182272 to ML. 
AUthor CONTRIBUTIONS-ML, RTP, CEH, GPL, ADS, RDS, LPQ, DC, and MFW, all authors, contributed to the study design, supplied plant material or DNA sequence data, and cowrote the paper.

\section{LiterATURE CITED}

Bailey, C. D., T. G. Carr, S. A. Harris, and C. E. Hughes. 2003. Characterization of angiosperm nrDNA polymorphism, paralogy and pseudogenes. Molecular Phylogenetics and Evolution 29: $435-455$.

Baldwin, B. G., M. J. Sanderson, J. M. Porter, M. F. Wojciechowski, C. S. Campbell, and M. J. Donoghue. 1995. The ITS region of nuclear ribosomal DNA: A valuable source of evidence on angiosperm phylogeny. Annals of the Missouri Botanical Garden 82: 247-277.

Darriba, D., G. L. Taboada, R. Doallo, and D. Posada. 2012. jModelTest 2: More models, new heuristics and parallel computing. Nature Methods 9: 772.

de Queiroz, K. 2007. Species concepts and species delimitation. Systematic Biology 56: 879886.

Dexter, K. G., M. Lavin, B. Torke, A. Twyford, T. Kursar, P. Coley, C. Drake, R. Hollands, and R. T. Pennington. 2017. Dispersal assembly of rain forest tree communities across the Amazon basin. Proceedings of the National Academy of Sciences USA 114: 2645-2650.

DRYFLOR. 2016. Plant diversity patterns in neotropical dry forests and their conservation implications. Science 353: 1383-1387.

Duno-de-Stefano, R., G. C. Fernández-Concha, L. L. Can-Itza, and M. Lavin. 2010. The morphological and phylogenetic distinctions of Coursetia greenmanii (Leguminosae): taxonomic and ecological implications. Systematic Botany 35: 289-295. 
Edgar, R. C. 2004. MUSCLE: Multiple sequence alignment with high accuracy and high throughput. Nucleic Acids Research 32: 1792-1797.

Felsenstein, J. 1985. Confidence limits on phylogeny: An approach using the bootstrap. Evolution 39: 783-791.

Fick, S. E. and R. J. Hijmans. 2017. WorldClim 2: new 1-km spatial resolution climate surfaces for global land areas. International Journal of Climatology 37: 4302-4315.

Gagnon, E., C. E. Hughes, G. P. Lewis, and A. Bruneau. 2015. A new cryptic species in a new cryptic genus in the Caesalpinia group (Leguminosae) from the seasonally dry inter-Andean valleys of South America. Taxon 64: 468-490.

Govindarajulu, R., C. E. Hughes, and C. D. Bailey. 2011. Phylogenetic and population genetic analyses of diploid Leucaena (Leguminosae-Mimosoideae) reveal cryptic species diversity and patterns of allopatric divergent speciation. American Journal of Botany 98: 2049-2063.

Guindon, S. and O. Gascuel. 2003. A simple, fast and accurate method to estimate large phylogenies by maximum-likelihood. Systematic Biology 52: 696-704.

Hijmans, R. J., J. Van Etten, J. Cheng, M. Mattiuzzi, M. Sumner, J. A. Greenberg, O. Perpinan Lamigueiro, A. Bevan, E. B. Racine, A. Shortridge, and A. Ghosh. 2016. raster: Geographic data analysis and modeling, version 2.5-8. https://cran.r-project.org/package=raster.

Hijmans, R. J., S. Phillips, J. Leathwick, and J. Elith. 2017. dismo: Species distribution modeling, version 1.1-4. https://cran.r-project.org/package=dismo.

Huelsenbeck, J. P. and F. Ronquist. 2001. MrBayes: Bayesian inference of phylogenetic trees. Bioinformatics 17: 754-755. 
Kay, K. M., J. B. Whittall, and S. A. Hodges. 2006. A survey of nuclear ribosomal internal transcribed spacer substitution rates across angiosperms: An approximate molecular clock with life history effects. BMC Evolutionary Biology 6: 36.

Lavin, M. 1988. Systematics of Coursetia (Leguminosae-Papilionoideae). Systematic Botany Monographs 21: 1-167.

Lavin, M. 2006. Floristic and geographic stability of discontinuous seasonally dry tropical forests explains patterns of plant phylogeny and endemism, Chapter 19. Pp. 433-447 in Neotropical savannas and seasonally dry forests: Plant biodiversity, biogeographic patterns and conservation, eds. R. T. Pennington, J. A. Ratter, and G. P. Lewis. Boca Raton, Florida: CRC Press.

Lavin, M. and M. Sousa S. 1995. Phylogenetic systematics and biogeography of the tribe Robinieae. Systematic Botany Monographs 45: 1-165.

Lavin, M., P. Herendeen, and M. F. Wojciechowski. 2005. Evolutionary rates analysis of Leguminosae implicates a rapid diversification of lineages during the Tertiary. Systematic Biology 54: 530-549.

Lavin, M., M. F. Wojciechowski, P. Gasson, C. H. Hughes, and E. Wheeler. 2003. Phylogeny of robinioid legumes (Fabaceae) revisited: Coursetia and Gliricidia recircumscribed, and a biogeographical appraisal of the Caribbean endemics. Systematic Botany 28: 387-409.

Lavin, M., R. T. Pennington, C. E. Hughes, G. P. Lewis, A. Delgado Salinas, R. Duno de Stefano, L. P. Queiroz, D. Cardoso, M. F. Wojciechowski. 2018. Data from: Sequence Variation among Conspecific Accessions of the Legume Coursetia caribaea Reveal Geographically Localized Clades Here Ranked as Species. Dryad Digital Repository. https://doi.org/10.5061/dryad.mv453. 
Müller, J., K. Müller, C. Neinhuis, and D. Quandt. 2010. Phylogenetic Data Editor, PhyDE-1, v0.9971 (http://www.phyde.de/index.html).

Naciri Y. and H. P. Linder. 2015. Species delimitation and relationships: The dance of the seven veils. Taxon 64: 3-16.

Paradis, E. 2013. Molecular dating of phylogenies by likelihood methods: A comparison of models and a new information criterion. Molecular Phylogenetics and Evolution 67: 436-444.

Paradis, E., S. Blomberg, B. Bolker, J. Brown, J. Claude, H. S. Cuong, R. Desper, G. Didier, B. Durand, J. Dutheil, R. J. Ewing, O. Gascuel, C. Heibl, A. Ives, B. Jones, F. Krah, D. Lawson, V. Lefort, P. Legendre, J. Lemon, R. McCloskey, J. Nylander, R. Opgen-Rhein, A.-A. Popescu, M. Royer-Carenzi, K. Schliep, K. Strimmer, and D. de Vienne. 2017. ape: Analyses of phylogenetics and evolution, version 5.0. https://cran.r-project.org/package=ape.

Paradis, E., J. Claude, and K. Strimmer. 2004. APE: Analyses of phylogenetics and evolution in R language. Bioinformatics 20: 289-290.

Pennington, R. T., A. Daza, C. Reynel, and M. Lavin 2011. Poissonia eriantha (Leguminosae) from Cuzco, Peru: An overlooked species underscores a pattern of narrow endemism common to seasonally dry neotropical vegetation. Systematic Botany 36: 59-68.

Pennington, R. T., M. Lavin, and A. Oliveira-Filho. 2009. Woody plant diversity, evolution and ecology in the tropics: Perspectives from seasonally dry tropical forests. Annual Review of Ecology Evolution and Systematics 40: 437-457.

Pennington, R. T., M. Lavin, T. Särkinen, G. Lewis, B. Klitgaard, and C. E. Hughes. 2010. Contrasting plant diversification histories within the Andean biodiversity hotspot. Proceedings of the National Academy of Sciences USA 107: 13783-13787. 
Pennington, R. T. and M. Lavin. 2016. The contrasting nature of woody plant species in different neotropical forest biomes reflects differences in ecological stability. New Phytologist 210: 2537.

Pennington, R. T., J. E. Richardson, and M. Lavin. 2006. Insights into the historical construction of species-rich biomes from dated plant phylogenies, neutral ecological theory and phylogenetic community structure. New Phytologist 172: 605-616.

Queiroz, L. P. de and M. Lavin. 2011. Coursetia (Leguminosae) from eastern Brazil: The monophyly of three caatinga-inhabiting species is revealed by nuclear ribosomal and chloroplast DNA sequence analysis. Systematic Botany 36: 69-79.

R Core Team. 2017. R: A language and environment for statistical computing. Vienna, Austria: R Foundation for Statistical Computing (https://www.R-project.org).

Ronquist, F. and J. P. Huelsenbeck. 2003. MrBayes 3.2.6: Bayesian phylogenetic inference under mixed models. Bioinformatics 19: 1572-1574.

Sanderson, M. J. 2002. Estimating absolute rates of molecular evolution and divergence times: A penalized likelihood approach. Molecular Biology and Evolution 19: 101-109.

Sanderson, M. J. 2012. r8s, version 1.8.1, User's manual. Distributed by the author, Tucson: Arizona (https://sourceforge.net/projects/r8s/).

Sandwith, N. Y. 1925. Humboldt and Bonpland's itinerary in Venezuela. Kew Bulletin 1925: 295310.

Särkinen, T. S., J. L. Marcelo Peña, A. D. Yomona, M. F. Simon, R. T. Pennington, and C. E. Hughes. 2011. Underestimated endemic species diversity in the Marañon seasonally dry tropical forests of Peru - an example from Mimosa (Leguminosae: Mimosoideae). Taxon 60: 139-150. 
Särkinen, T., R. T. Pennington, M. Lavin, M. F. Simon, and C. E. Hughes. 2012. Evolutionary islands in the Andes: Persistence and isolation explain high endemism in Andean dry tropical forests. Journal of Biogeography 39: 884-900.

Shaw, J., E. B. Lickey, J. T. Beck, S. B. Farmer, W. Liu, J. Miller, K. C. Siripun, C. T. Winder, E. E. Schilling, and R. L. Small. 2005. The tortoise and the hare II: Relative utility of 21 noncoding chloroplast DNA sequences for phylogenetic analysis. American Journal of Botany 92: $142-166$.

Song, J., L. Shi, D. Li, Y. Sun, Y. Niu, Z. Chen, H. Luo, X. Pang, Z. Sun, C. Liu, A. Lv, Y. Deng, Z. Larson-Rabin, M. Wilkinson, S. Chen. 2012. Extensive pyrosequencing reveals frequent intra-genomic variations of internal transcribed spacer regions of nuclear ribosomal DNA. PLoS One 7: e43971.

Sousa, M. and M. Lavin. 1986. Balboa (Fabaceae, Millettieae) reduced to Cracca (Robinieae). Brittonia 38: 302-304.

Swofford, D. L. 2002. PAUP*. Phylogenetic Analysis Using Parsimony (*and Other Methods). Version 4. Sinauer Associates, Sunderland, Massachusetts. Available at http://paup.phylosolutions.com/.

Thiers, B. 2017. Index Herbariorum: A global directory of public herbaria and associated staff. New York Botanical Garden's Virtual Herbarium (http://sweetgum.nybg.org/science/ih/). Yang, Z. and B. Rannala. 1997. Bayesian phylogenetic inference using DNA sequences: A Markov Chain Monte Carlo method. Molecular Biology and Evolution 14: 717-724. 
TABLE 1. Summary of the 11 Robinieae genera and 77 species sampled for DNA sequence data from the nrDNA ITS region.

\begin{tabular}{|c|c|c|c|c|}
\hline Genus & $\begin{array}{l}\text { Species } \\
\# \\
\text { (77 total) }\end{array}$ & $\begin{array}{l}\text { \# sampled species/accessions } \\
\text { (species not sampled) }\end{array}$ & Geographic distribution & $\begin{array}{l}\text { SDTF, tropical wet } \\
\text { forests, pine-oak } \\
\text { woodlands }\end{array}$ \\
\hline Gliricidia Kunth & 5 & $5 / 51$ & Mesoamerica & $\begin{array}{l}\text { SDTF, tropical wet } \\
\text { forests, pine-oak } \\
\text { woodlands }\end{array}$ \\
\hline Poitea Ventenat & 12 & $\begin{array}{l}11 / 34 \\
\text { (Poitea longifolia } \text { Urb.) }\end{array}$ & $\begin{array}{l}\text { Cuba, Hispaniola, Puerto } \\
\text { Rico, Virgin Islands, } \\
\text { Dominica }\end{array}$ & $\begin{array}{l}\text { SDTF, tropical wet } \\
\text { forests, pine woodlands }\end{array}$ \\
\hline Hebestigma Urb. & 1 & $1 / 9$ & Cuba & SDTF \\
\hline Lennea Klotzsch & 3 & $3 / 5$ & Mesoamerica & $\begin{array}{l}\text { SDTF, tropical wet } \\
\text { forests }\end{array}$ \\
\hline Robinia L. & 4 & $4 / 12$ & $\begin{array}{l}\text { Southern USA, northern Sierra } \\
\text { Madre Occidental, Mexico }\end{array}$ & $\begin{array}{l}\text { Temperate deciduous } \\
\text { forests }\end{array}$ \\
\hline Poissonia Baill. & 5 & $5 / 33$ & $\begin{array}{l}\text { Southern Andes, Peru, } \\
\text { Bolivia, northern Argentina }\end{array}$ & $\begin{array}{l}\text { SDTF, Arequipa and } \\
\text { monte deserts }\end{array}$ \\
\hline $\begin{array}{l}\text { Sphinctospermum } \\
\text { Rose }\end{array}$ & 1 & $1 / 9$ & $\begin{array}{l}\text { Southwestern USA, Pacific } \\
\text { coastal Mexico }\end{array}$ & SDTF \\
\hline $\begin{array}{l}\text { Genistidium } \\
\text { I.M.Johnston }\end{array}$ & 1 & $1 / 3$ & $\begin{array}{l}\text { Chihuahuan Desert, Mexico } \\
\text { and USA }\end{array}$ & SDTF \\
\hline
\end{tabular}




\begin{tabular}{|c|c|c|c|c|}
\hline Peteria A.Gray & 4 & $\begin{array}{l}3 / 5 \\
\text { (Peteria pinetorum C.L.Porter) }\end{array}$ & $\begin{array}{l}\text { Mainly southwestern USA and } \\
\text { northern Mexico }\end{array}$ & $\begin{array}{l}\text { SDTF, temperate shrub } \\
\text { steppe }\end{array}$ \\
\hline Olneya A.Gray & 1 & $1 / 12$ & $\begin{array}{l}\text { Sonoran Desert, Mexico and } \\
\text { USA }\end{array}$ & SDTF \\
\hline Coursetia DC. & 40 & $\begin{array}{l}38 / 265 \\
\text { (Coursetia intermontana Lavin } \\
\text { and C. tumbezensis MacBride) }\end{array}$ & $\begin{array}{l}\text { Southwestern USA, } \\
\text { Mesoamerica, South America, } \\
\text { Lesser Antilles }\end{array}$ & $\begin{array}{l}\text { SDTF, pine-oak } \\
\text { woodlands }\end{array}$ \\
\hline
\end{tabular}


TABLE 2. Results of the evolutionary rates analysis of nrDNA ITS sequences. Reported rate and age estimates compare to an overall expected mean rate of 0.0025 substitutions per site per Ma $\left(2.5 \times 10^{-9}\right.$ substitutions per site per year $)$ and an expected mean age of 8.6 Ma for 72 nrDNA ITS stem clades of species of Robinieae (Pennington and Lavin 2016). Our overall mean rate of substitution for the nrDNA ITS region is slightly faster than a woody plant mean estimate of $2.15 \times 10^{-9}$ substitutions per site per year (Kay et al. 2006).

\begin{tabular}{|c|c|c|c|c|c|c|}
\hline Clade & MRCA of: & & Mean & & Mean & Standard \\
\hline Coursetia astragalina crown & $\begin{array}{l}\text { Coursetia caribaea } \\
\text { astragalina } \mathrm{KX} 235193\end{array}$ & $\begin{array}{l}\text { Coursetia caribaea } \\
\text { astragalina } \mathrm{KX} 235187\end{array}$ & 0.0034 & 0.0003 & 0.0 & 0.0 \\
\hline Coursetia astragalina stem & $\begin{array}{l}\text { Coursetia caribaea } \\
\text { astragalina } \mathrm{KX} 235193\end{array}$ & $\begin{array}{l}\text { Coursetia gracilis } \\
\text { KX235182 }\end{array}$ & 0.0040 & 0.0002 & 11.0 & 1.3 \\
\hline Coursetia ochroleuca crown & $\begin{array}{l}\text { Coursetia caribaea } \\
\text { ochroleuca } \mathrm{KX} 235216\end{array}$ & $\begin{array}{l}\text { Coursetia caribaea } \\
\text { ochroleuca AF398847 }\end{array}$ & 0.0012 & 0.0008 & 1.5 & 0.6 \\
\hline Coursetia ochroleuca stem & $\begin{array}{l}\text { Coursetia caribaea } \\
\text { ochroleuca } \mathrm{KX} 235216\end{array}$ & $\begin{array}{l}\text { Coursetia caribaea pacifica } \\
\text { GQ996224 }\end{array}$ & 0.0025 & 0.0005 & 7.7 & 1.4 \\
\hline Coursetia diversifolia crown & $\begin{array}{l}\text { Coursetia caribaea pacifica } \\
\text { KT281089 }\end{array}$ & $\begin{array}{l}\text { Coursetia caribaea pacifica } \\
\text { GQ996224 }\end{array}$ & 0.0024 & 0.0007 & 0.0 & 0.0 \\
\hline Coursetia diversifolia stem & $\begin{array}{l}\text { Coursetia caribaea } \\
\text { ochroleuca } \mathrm{KX} 235216\end{array}$ & $\begin{array}{l}\text { Coursetia caribaea pacifica } \\
\text { GQ996224 }\end{array}$ & 0.0025 & 0.0005 & 7.7 & 1.4 \\
\hline
\end{tabular}

Other clades 


\begin{tabular}{|c|c|c|c|c|c|c|}
\hline Coursetia caribaea var. & Coursetia caribaea sericea & Coursetia caribaea sericea & 0.0017 & 0.0008 & 0.0 & 0.0 \\
\hline sericea crown & GQ996226 & KT281104 & & & & \\
\hline Coursetia caribaea var. & Coursetia caribaea sericea & Coursetia caribaea & 0.0017 & 0.0006 & 4.2 & 0.7 \\
\hline sericea stem & GQ996226 & KT281097 & & & & \\
\hline Coursetia caribaea var. & Coursetia caribaea & Coursetia caribaea & 0.0016 & 0.0007 & 3.0 & 0.5 \\
\hline trifoliolata crown & trifoliolata KT281079 & trifoliolata AF542463 & & & & \\
\hline Coursetia caribaea var. & Coursetia caribaea & Coursetia caribaea & 0.0014 & 0.0007 & 7.2 & 1.2 \\
\hline trifoliolata stem & trifoliolata KT281079 & GQ996223 & & & & \\
\hline Coursetia caribaea var. & Coursetia caribaea & Coursetia pumila & 0.0011 & 0.0007 & 2.0 & 0.5 \\
\hline tomentosa stem & tomentosa GQ996225 & AF542462 & & & & \\
\hline
\end{tabular}


TABLE 3. Results of the evolutionary rates analysis of $\operatorname{trn} D$-trnT sequences. Reported rate and age estimates compare to an overall mean rate of 0.0008 substitutions per site per Ma $\left(0.8 \times 10^{-9}\right.$ substitutions per site per year $)$ and an expected mean age of 7.9 Ma for 28 trnD-trnT stem clades of species of Robinieae (M. Lavin unpubl. data).

\begin{tabular}{|c|c|c|c|c|c|c|}
\hline Clade & MRCA of: & & & & & \\
\hline Coursetia astragalina crown & $\begin{array}{l}\text { Coursetia caribaea } \\
\text { astragalina } \mathrm{KX} 235220\end{array}$ & $\begin{array}{l}\text { Coursetia caribaea } \\
\text { astragalina } \mathrm{KX} 235222\end{array}$ & 0.0009 & 0.0002 & 0.0 & 0.0 \\
\hline Coursetia astragalina stem & $\begin{array}{l}\text { Coursetia caribaea } \\
\text { astragalina } \mathrm{KX} 235220\end{array}$ & $\begin{array}{l}\text { Coursetia hassleri } \\
\text { KP990771 }\end{array}$ & 0.0008 & 0.0002 & 4.2 & 1.2 \\
\hline Coursetia ochroleuca crown & $\begin{array}{l}\text { Coursetia caribaea } \\
\text { ochroleuca KP990790 }\end{array}$ & $\begin{array}{l}\text { Coursetia caribaea } \\
\text { ochroleuca KP990791 }\end{array}$ & 0.0008 & 0.0002 & 0.3 & 0.1 \\
\hline Coursetia ochroleuca stem & $\begin{array}{l}\text { Coursetia caribaea pacifica } \\
\text { KP990785 }\end{array}$ & $\begin{array}{l}\text { Coursetia caribaea } \\
\text { ochroleuca KP990789 }\end{array}$ & 0.0008 & 0.0002 & 2.9 & 0.6 \\
\hline Coursetia diversifolia crown & $\begin{array}{l}\text { Coursetia caribaea pacifica } \\
\text { KP990785 }\end{array}$ & $\begin{array}{l}\text { Coursetia caribaea pacifica } \\
\text { KP990786 }\end{array}$ & 0.0008 & 0.0002 & 0.0 & 0.0 \\
\hline Coursetia diversifolia stem & $\begin{array}{l}\text { Coursetia caribaea pacifica } \\
\text { KP990785 }\end{array}$ & $\begin{array}{l}\text { Coursetia caribaea } \\
\text { ochroleuca KP990789 }\end{array}$ & 0.0008 & 0.0002 & 2.9 & 0.6 \\
\hline
\end{tabular}


FIG. 1. Bayesian majority rule consensus phylogeny of the nrDNA ITS region sampled from the legume tribe Robinieae and outgroup tribes Sesbanieae and Loteae and showing only the relevant portion that includes the samples of Coursetia caribaea vars. astragalina, ochroleuca, and pacifica (see Fig. S1 for all 489 terminal taxa). Numbers above the branches are Bayesian posterior probabilities. Numbers below the branches are parsimony bootstrap percentages for selected clades also resolved in the strict consensus tree of the parsimony analysis. The label "Coursetia caribaea" at the top marks the crown clade of that species. Both the parsimony and Bayesian analysis resolved this clade.

FIG. 2. Bayesian majority rule consensus phylogeny of the combined nrDNA ITS and trnD$\operatorname{trnT}$ region sampled from the legume tribe Robinieae and outgroup tribes Sesbanieae and Loteae and showing part of the phylogeny with all Coursetia samples, primarily those of C. caribaea var. caribaea, C. astragalina, C. ochroleuca, and C. diversifolia (see Fig. S3 for all 181 terminal taxa). Numbers above the branches are Bayesian posterior probabilities. Numbers below the branches are parsimony bootstrap percentages for selected clades also resolved in the strict consensus tree of the parsimony analysis.

FIG. 3. Geographic distribution of DNA samples of Coursetia species. A. Distribution of Coursetia astragalina (C. caribaea var. astragalina) and the rest of the Coursetia grandiflora clade. B. Distribution of Coursetia caribaea var. caribaea, C. ochroleuca (C. caribaea var. ochroleuca), and C. diversifolia (C. caribaea var. pacifica). These sites encompass the geographic extent of each of these taxa (e.g., Lavin 1988; Supplemental Map). Samples of Coursetia caribaea var. caribaea came from sites located near those of the other seven varieties 
of this species. Coursetia caribaea var. caribaea is relatively uncommon in South America; hence, samples from Colombia, Ecuador, Peru, and Bolivia are few. The mean annual precipitation model comes from Fick and Hijmans (2017). 